\title{
Optimalisasi Manajemen Perpustakaan dan Signifikansinya Bagi Peningkatan Mutu Pembelajaran di Sekolah/Madrasah
}

\author{
Mohammad Mansyur \\ UIN Sunan Ampel Surabaya \\ E-mail: syurya63@gmail.com
}

\begin{abstract}
Abstrak: Perpustakaan di sekolah/madrasah berperan besar dalam proses pendidikan sepanjang hayat, di samping mendukung tercapainya tujuan proses pembelajaran dan menumbuhkan minat baca siswa. Namun eksistensi perpustakaan sekolah/madarasah sebagai sumber belajar belum dimanfaatkan secara optimal oleh warga sekolah. Artikel ini mengkaji optimalisasi manajemen perpustakaan sekolah/madrasah dalam meningkatkan mutu proses pembelajaran. Tulisan ini menunjukkan bahwa perpustakaan merupakan tempat informasi dan ilmu pengetahuan diseleksi, diadakan, diorganisasi, disimpan, dipelihara, digunakan dan dipinjamkan. Manajemen perpustakaan merupakan kajian tentang apa dan bagaimana cara yang dapat dilakukan, baik melalui teori maupun praktek, agar perpustakaan dapat dikelola dengan berdaya guna. Manajemen perpustakaan sekolah meliputi perencanaan, pengorganisasian, pengaturan staf, pengarahan dan pengendalian. Pustakawan adalah orang yang ahli membantu memudahkan akses ke informasi dan ilmu pengetahuan yang dibutuhkan oleh para masyarakat dan pemustaka lainnya. Pustakawan dituntut untuk memiliki keahlian dan keterampilan dalam mengelola informasi dan ilmu pengetahuan serta memahami kebutuhan para pemustaka. Pengelola perpustakaan juga harus dapat mengelola perpustakaan secara efektif, sehingga kebijakan sekolah, yayasan, pemerintah dan kebijakan lainnya dapat dijalankan dan prosedur yang dijalankan sesuai dengan kebutuhan-kebutuhan sekolah.
\end{abstract}

\section{Kata kunci: Manajemen, Perpustakaan, Mutu Pembelajaran, Pustakawan}

Abstract: Library has an important role in school/madrasa for educational process lastingly. It supports the learning process achievemnet aims and fosters student interest in reading. In fact, school community has not used the library as learning sources optimally. This article discusses the optimization of school/madrasa library management to improve the learning process quality. The result shows that the library is a place in which information and knowledge are selected, held, organized, stored, maintained, used and borrowed. Library management is a study about what and how come something be done through theory and practice, so the library can be managed efficiently, such school library management as planning, organizing, staffing, directing and controlling. Librarians are people who are experts in helping facilitate access to information and knowledge needed by public and other users. Librarians are required to have proficiency and skills in managing information and knowledge, and they have to understand the user's needs as well. The manager must be able to manage the library effectively, and resulted school policies, foundations, government and other policies can be carried out then they are in accordance with the shool needs.

Keywords: Management, Library, Learning Quality, Librarian

\section{PENDAHULUAN}

Perpustakaan yang diselenggarakan di tingkat sekolah/madrasah berfungsi mendukung tercapainya tujuan dari proses pembelajaran dan menumbuhkan minat baca siswa sehingga tumbuh kesadaran untuk dapat belajar mandiri, 
sehingga kualitas sumber daya manusia mampu terwujud. ${ }^{1}$ Kurikulum Tahun 2013 (K-13) merupakan kurikulum operasional yang disusun dan dilaksanakan oleh masing-masing satuan pendidikan. Implementasi dan pengembangan K-13 sangat membutuhkan sumber-sumber informasi penting dalam proses pembelajaran bagi siswa, terutama perpustakaan. Pengelolaan perpustakaan bertugas mendukung dalam merealisasikan K-13, terutama dalam mencapai tujuan pembelajaran di sekolah.

Keberadaan perpustakaan saat ini menjadi sangat penting setelah pemberlakuan Kurikulum Tingkat Satuan Pendidikan (KTSP). ${ }^{2}$ Perpustakaan sekolah diharapkan dapat menunjang proses pembelajaran di sekolah/madrasah. Perpustakaan sekolah perlu dikembangkan sehingga bisa berfungsi sebagai sumber belajar bagi warga sekolah/madrasah.

Pada masa pandemi Covid-19 pun, peran perpustakaan dalam kegiatan belajar mengajar daring (online) memiliki peran penting, terutama dalam hal pemenuhan kebutuhan informasi bagi para pemustaka, seperti memaksimalkan penggunaan e-resource yang ada di perpustakaan, membuka layanan online via whastapp dan media sosial terkait dengan kebutuhan infromasi yang mungkin tidak ditemukan pada layanan e-resource. ${ }^{3}$

Perpustakaan merupakan sumber ide-ide baru yang dapat mendorong kemauan para siswa untuk dapat berpikir secara rasional dan kritis serta memberikan petunjuk untuk mencipta. ${ }^{4}$ Perpustakaan akan memberikan jawaban yang cukup memuaskan bagi para siswa, sebagai tuntutan rasa keingintahuan terhadap sesuatu, benar-benar telah terbangun. Kumpulan bahan pustaka (koleksi) di perpustakaan memberikan kesempatan membaca bagi para siswa yang mempunyai waktu dan kemampuan yang beraneka ragam. Perpustakaan dapat menimbulkan cinta membaca, sehingga dapat mengarahkan selera dan apresiasi siswa dalam pemilihan bacaan.

Jika minat membaca sudah tumbuh dan berkembang pada diri siswa, maka perpustakaan juga dapat mengurangi jajan anak, yang ini biasanya dapat berpengaruh negatif terhadap kesehatan anak. Bahkan perpustakaan juga bagi anak-anak dapat menjauhkan diri dari tindakan kenakalan, yang bisa menimbulkan suasana kurang sehat dalam hubungan berteman diantara mereka. ${ }^{5}$

${ }^{1}$ Arief Rachman Badrudin, "Manajemen Perpustakaan Sekolah dalam Merealisasikan Pengembangan Kurikulum 2013," Jurnal Islamic Management, Vol. 2 No. 1 (2019), 1-17.

2Darmono, "Pengembangan Perpustakaan Sekolah Sebagai Sumber Belajar," Jurnal Perpustakaan Sekolah, Vol. 1 No. 1 (2007), 1-9.

${ }^{3}$ Arja Kusuma, "Dukungan Perpustakaan dalam Proses Pembelajaran Online di Universitas Islam Negeri Sunan Kalijaga pada Masa Pandemic Covid-19," Jurnal Libria, Vol. 12 No. 1 (Juni 2020), 51-70.

${ }^{4}$ Alias Mangnga, "Peran Perpustakaan Sekolah Terhadap Proses Belajar Mengajar di Sekolah," Jurnal Jupiter, Vol. XIV No. 1 (2015), 38-40.

5Ibid, 40-41. 
Perpustakaan sekolah bertugas menyediakan layanan pembelajaran, buku dan sumber informasi lain sehingga menjadikan seluruh warga masyarakat sekolah menjadi pemikir kritis (critical thinkers) dan pemakai efektif informasi dalam beragam media dan format. ${ }^{6}$ Kebijakan ini mencakup tujuan dan prioritas layanan sehubungan dengan kurikulum sekolah yang berlaku. Perpustakaan sekolah juga harus diselenggarakan dan dikelola berdasar standar profesional. Layanan harus dapat diakses oleh setiap anggota masyarakat sekolah dan diselenggarakan berdasar konteks masyarakat setempat.

Buku, dalam dunia pendidikan, terbukti berdaya guna dan bertepat guna sebagai salah satu sarana pendidikan dan sarana komunikasi. Dalam kaitan inilah perpustakaan dan pelayanan perpustakaan harus dikembangkan sebagai salah satu institusi untuk mewujudkan tujuan mencerdaskan kehidupan bangsa. Perpustakaan merupakan bagian yang vital dan besar pengaruhnya terhadap mutu pendidikan. ${ }^{7}$

Perpustakaan sekolah/madrasah berperan dalam proses pendidikan sepanjang hayat.8 Perpustakaan sekolah diharapkan juga mampu untuk memberikan kontribusi dalam peningkatan mutu pendidikan dan upaya menumbuhkan minat baca. Hal ini dikarenakan minat baca siswa yang meningkat akan berimbas kepada kemajuan pendidikan di Indonesia serta mampu mengarahkan kepada tujuan negara, yaitu mencerdaskan kehidupan bangsa.

Minat baca masyarakat yang rendah sangat mempengaruhi kualitas bangsa Indonesia, sebab dengan rendahnya minat baca maka tidak bisa mengetahui dan mengikuti perkembangan ilmu pengetahuan dan informasi di dunia. ${ }^{9}$ Penelitian Gallint Rahadian menunjukkan bahwa pustakawan, koleksi dan pengelolaan di perpustakaan mempunyai peran dalam meningkatkan budaya gemar membaca siswa. ${ }^{10}$

Namun eksistensi perpustakaan sekolah/madarasah sebagai pusat sumber belajar masih belum dimanfaatkan secara optimal oleh masyarakat sekolah. Pemanfaatan perpustakaan sekolah masih belum maksimal karena penyelenggaraan perpustakaan sekolah yang kurang baik, sehingga kurang optimal pemanfaatannya. ${ }^{11}$

\footnotetext{
${ }^{6}$ Blasius Sudarsono, "Perpustakaan Sekolah Suatu Keniscayaan dalam Penyelenggaraan Pendidikan Formal," Jurnal Acarya Pustaka, Vol. 1 No. 2 (2015).

${ }^{7}$ Alias Mangnga, "Peran Perpustakaan Sekolah," 41.

${ }^{8}$ https://perpusda.bengkuluprov.go.id/2018/02/12/peranan-perpustakaan-sekolah-dalamproses-belajar-mengajar/, diunduh 12 Agustus 2021, pukul 20.07 WIB

9Ika Kartika, "Upaya Pemanfaatan Perpustakaan Sekolah Dalam Meningkatkan Minat Baca Siswa Di Sekolah Dasar Negeri 1 Pamengkang Kecamatan Mundu Kabupaten Cirebon," Jurnal EduBase, Vol. 1 No. 1 (2020), 65-83.

${ }^{10}$ Gallint Rahadian, "Peran Perpustakaan dalam Meningkatkan Budaya Gemar Membaca," Jurnal Kajian Informasi dan Perpustakaan, Vol. 2 No. 1 (2014), 27-36.

${ }^{11}$ Rio Novriliam, "Pemanfaatan Perpustakaan Sekolah Sebagai Pusat Sumber Belajar di SDN 23 Painan Utara," Jurnal Ilmu Informasi Perpustakaan dan Kearsipan, Vol. 1 No. 1 (September 2012), 141-150.
} 
Artikel ini akan mengkaji optimalisasi manajemen perpustakaan sekolah/madrasah dalam mendukung peningkatan mutu proses pembelajaran. Kajian ini penting dilakukan mengingat perpustakaan adalah elemen vital dalam memajukan mutu pendidikan di sebuah sekolah/madrasah, terutama sebagai sumber ilmu pengetahuan dan pusat kegiatan belajar.

\section{METODE PENELITIAN}

Artikel ini adalah hasil penelitian kualitatif dengan menggunakan metode deskriptif-kualitatif. Metode ini digunakan dalam meneliti status kelompok manusia, suatu objek, sistem pemikiran ataupun meneliti suatu peristiwa pada masa sekarang, bertujuan untuk membuat gambaran secara sistematis, faktual dan akurat mengenai fakta-fakta, sifat-sifat serta hubungan antar fenomena yang diselidiki. Sumber data penelitian ini adalah segala sesuatu tentang sosok yang dikaji, baik berupa tulisan, kata-kata, acuan manusia dan informasi digital.12

Instrumen penggalian data dalam artikel ini menggunakan dokumentasi. ${ }^{13}$ Dokumentasi dalam artikel ini digunakan untuk menyelidiki barang-barang tertulis, seperti artikel jurnal, buku, majalah, koran, dokumen, sumber internet, foto dan lain sebagainya.

Analisis data dalam artikel ini menempuh langkah reduksi data, display data dan pengambilan kesimpulan (conclusion). ${ }^{14}$ Agar kesimpulan tidak kabur dan tidak diragukan, maka dalam tahap analisis kesimpulan itu harus diverifikasi dan dengan bertambahnya data yang diperoleh, kesimpulan itu bisa lebih sohih. Langkah ini dimulai dengan mencari pola, tema, hubungan, hal-hal yang sering timbul dan lain sebagainya yang mengarah kepada dua tujuan penulisan artikel di atas. Teknik triangulasi dalam artikel ini juga digunakan untuk melakukan pemeriksaan keabsahan data dengan memanfaatkan sesuatu yang lain di luar data itu untuk keperluan pengecekan atau sebagai pembanding terhadap data itu, terutama triangulasi sumber dan waktu.

\section{PEMBAHASAN}

\section{A. Manajemen Perpustakaan Sekolah}

Perpustakaan berasal dari bahasa Indonesia yang penterjemahannya dari kata library. Asal library dari kata liber yang berasal dari bahasa latin yang berarti buku. Sedangkan perpustakaan diambil bari kata pustaka yang berarti buku. Dengan demikian secara umum perpustakaan dapat diartikan sebagai kumpulan buku-buku. ${ }^{15}$ Dengan perkembangan informasi dan teknologi, maka perpustakaan sekarang ini tidak hanya mengoleksi buku saja, tetapi

${ }^{12}$ Noeng Muhajir, Metodologi Penelitian Kualitatif (Yogyakarta: Reke Sarasen, 1994), 38.

${ }^{13}$ Sutrisno Hadi, Metodologi Research (Yogyakarta: Andi Offset, 1987), 136.

${ }^{14}$ Mathew B Niles dan A. Michael Haberman, Qualitatif Data Analisis (London: tp, 1986), 177.

${ }^{15}$ Mohammad Mansyur, Manajemen Perpustakaan Sekolah/Madrasah (Jombang: Ainun Media, 2021), 17-23. 
berkembang koleksinya bahan-bahan informasi dan ilmu pengetahuan dalam berbagai format baik cetak maupun non cetak, misalnya film, slide, kaset, CD room dan lain-lain.

Secara terminologi, perpustakaan merupakan tempat di mana informasi ilmu pengetahuan itu diseleksi, diadakan, diorganisasi, disimpan, dipelihara, digunakan dan atau dipinjamkan. Dengan demikian, banyak kegiatan yang dilakukan dalam perpustakaan.

Pertama adalah diseleksi, yaitu bahwa perpustakaan itu tidak mungkin untuk mengoleksi seluruh informasi dan ilmu pengetahuan yang ada didunia ini. Karena adanya keterbatasan dana, tenaga yang mengelola, tempat untuk menyimpan, dan kebutuhan penggunanya, maka perpustakaan perlu adanya penyeleksian agar koleksi yang diadakan itu akan sesuai dengan kebutuhan penggunanya serta menyesuaikan dengan dana, tenaga dan ruang yang tersedia.

Kedua adalah diadakan, yaitu setelah koleksi diseleksi sudah sesuai dengan kebutuhan, maka langkah selanjutnya perpustakaan melakukan pengadaan koleksi. Pengadaan koleksi adalah kegiatan dimana perpustakaan melakukan pembelian ke distributor, toko buku, atau langsung ke penerbit terhadap koleksi yang telah terseleksi. Selain melakukan pengan pengadaan dengan cara pembelian, perpustakaan juga dapat menerima hadiah, hibah atau tukar-menukar.

Ketiga adalah diorganisasi, yaitu bahwa bahan-bahan informasi dan ilmu pengetahuan yang berupa buku, media elektronik, koran, jurnal dan lain-lain diadakan oleh perpustakaan, bahan tersebut selanjutnya akan diproses untuk diorganisasi. Kegiatan ini meliputi penulisan inventaris, pengklasifikasian, pengkatalogisasian, pengetikan dan penempelan label sampai meletakkan koleksi di rak yang sesuai dengan nomor klasifikasinya. Pengorganisasian ini dilakukan untuk memudahkan para pengguna dalam mengalokasikan informasi dan ilmu pengetahuan yang dibutuhkan secara cepat, mudah dan tepat.

Keempat adalah disimpan, bahwa semua bahan-bahan informasi dan ilmu pengetahuan tersebut didimpan di gedung perpustakaan. Penempatan koleksi ini dapat berupa rak-rak buku atau lemari-lemari, bahkan data-data yang ada di perpustakaan dapat disimpan di harddisk atau CD room. Hal ini dimaksudkan untuk memudahkan para pengguna mencari bahan-bahan informasi dan ilmu pengetahuan yang berada dalam satu gedung.

Kelima adalah dipelihara, yaitu bahwa kegiatan perpustakaan yang lain dan tidak kalah pentingnya adalah pemeliharaan. Kegiatan ini dilakukan karena banyak diketahui bahwa koleksi yang sering dipakai cenderung rusak, baik ringan ataupun berat. Jika koleksi yang rusak dibiarkan, maka koleksi tersebut lama-kelamaan akan tidak mungkin lagi dipakai. Selain koleksi yang rusak karena pemakaian, pemeliharaan ini juga penting karena faktor alam, misalnya kelembaban udara, temperatur, cahaya dan serangga. Untuk mencegah 
kerusakan-kerusakan tersebut, maka koleksi perpustakaan sangat perlu sekali dilakukan pemeliharaan.

Keenam adalah digunakan, yaitu koleksi perpustakaan dapat digunakan oleh para pengguna perpustakaan di ruang perpustakaan itu sendiri. Karena di perpustakaan telah disediakan fasilitas untuk membaca, misalnya meja dan kursi baca.

Ketujuh adalah dipinjamkan, yaitu koleksi perpustakaan yang bukan katagori referensi dapat dipnjamkan oleh para pengguna yang telah terdaftar sebagai anggota perpustakaan. Lama peminjaman koleksi tergantung dari kebijakan perpustakaan itu sendiri.

Ketujuh kegiatan yang dilakukan di perpustakaan tersebut akan dapat tercapai jika ada pustakawan dan staf perpustakaan. Pustakawan adalah orang yang ahli membantu dan memudahkan ke akses informasi dan ilmu pengetahuan yang dibutuhkan oleh penggunanya. Sehubungan dengan pelayanan perpustakaan kepada pengguna, pustakawan bertindak sebagai fasilitator yang bertugas untuk memudahkan akses dalam rangka untuk mendapatkan informasi dan ilmu pengetahuan yang mereka butuhkan.

Manajemen perpustakaan, di satu sisi, merupakan salah satu kajian tentang apa dan baigaimana cara yang dapat dilakukan, baik melalui teori maupun praktek agar perpustakaan dapat dikelola dengan berdaya guna dan berhasil guna sehingga keberadaannya di tengah masyarakat mampu menyeleksi, menghimpun, mengolah, memelihara sumber informasi dan memberikan layanan, serta nilai tambah bagi mereka yang membutuhkan.

Menurut Sutarno NS, manajemen perpustakaan adalah pengelolaan perpustakaan yang didasarkan pada teori dan prinsip-prinsip manajemen. Teori manajemen yaitu suatu konsep pemikiran atau pendapat yang dikemukakan mengenai bagaimana ilmu manajemen diterapkan dalam suatu organisasi/perpustakaan. Semenara prinsip manajemen adalah dasar atau asas kebenaran yang menjadi pokok pikiran dalam manajemen. ${ }^{16}$

Manajemen yang berkualitas menjadi keniscayaan bagi upaya mempertahankan perpustakaan sebagai sumber informasi utama bagi para siswa. Penyesuaian dengan perkembangan zaman sangat ditentukan oleh kualitas manajemen yang ada di perpustakaan sekolah. Dengan adanya manajemen berkualitas, perpustakaan dapat mengubah konsep, bentuk dan desain ruang perpustakaan menjadi sesuatu yang menarik untuk mewadahi dan memfasilitasi kebutuhan pemustaka yang sarat dengan teknologi dan bukan hanya memberikan pemandangan tumpukan buku di rak. Sehingga informasi yang ada di perpustakaan tidak terbatas dapat diakses secara konvensional yang menghabiskan waktu berjam-jam, melainkan dapat diakses dengan cepat dan memuaskan.

${ }^{16}$ Sutarno NS, Membina Perpustakaan Desa (Jakarta: CV. Sagung Seto, 2008), 23. 
Mengenai penyesuaian zaman dengan cara mengembangkan teknologi informasi dan komunikasi dapat dilihat dalam amanat UU Nomor 43 Tahun 2007 pasal 23 ayat 5. Tujuan perpustakaan secara umum dalam UU ini tidak lain adalah memberikan layanan kepada pemustaka, meningkatkan kegemaran membaca, serta memperluas wawasan dan pengetahuan untuk mencerdaskan kehidupan bangsa. Dengan demikian, manajemen yang baik dan berkualitas dapat memikat hati para siswa untuk berkunjung ke perpustakaan sekolah/madrasah.

Manajemen dalam perpustakaan sekolah bukan hanya kegiatan menempatkan buku-buku di rak, namun sangat kompleks, berkelanjutan dan selalu berubah. Jadi manajemen merupakan sebuah proses yang mengarah kepada perbaikan hasil kegiatan dalam mencapai tujuan sekolah. Kegiatan manajemen perpustakaan merupakan bagian lain keterlibatan tenaga kependidikan yang mengelola perpustakaan dalam pendidikan di sekolah. Dalam hal ini kegiatan perpustakaan sekolah harus mampu mendukung kurikulum dan program-program sekolah.

Sedangkan perpustakaan sekolah/madrasah adalah perpustakaan yang tergabung pada sebuah madrasah sekolah, dikelola sepenuhnya oleh madrasah sekolah yang bersangkutan, dengan tujuan utama membantu sekolah untuk mencapai tujuan khusus sekolah dan tujuan pendidikan pada umumnya. ${ }^{17}$

Manajemen perpustakaan sekolah/madrasah adalah suatu proses kegiatan yang dilaksanakan perpustakaan sekolah untuk mencapai sasaran seefisien mungkin dengan mendayagunakan semua sumber daya yang ada, meliputi SDM, sarana, metode dan dana. Perpustakaan sekolah/madrasah melaksanakan hal-hal tersebut disertai dengan pencapaian tujuan pendidikan maupun tujuan madrasah atau sekolah melalui jasa layanannya dan kegiatan perpustakaan lainnya yang menunjang kurikulum dan kegiatan belajar mengajar di madrasah atau sekolah. Dengan demikian perpustakaan dapat menjadi salah satu sarana sumber belajar yang harus dikelola dengan manajemen terbaiknya.

Pengelolaan perpustakaan berdasarkan manajemen ini berkaian dengan bagaimana perpustakaan membuat perencanaan, menentukan tujuan, kebijakan, dan standart operasional yang jelas sehingga perpustakaan dapat berperan dalam proses pembelajaran. Hal ini dapat tercapai jika dijalankan seluruh fungsi- fungsi manajemen yang ada.

Perpustakaan, termasuk juga perpustakaan sekolah/madrasah sudah seharusnya melaksanakan fungsi manajemen sebagai dasar pengelolaannya, yaitu planning (perencanaan), organizing (pengorganisasian), staffing (pengaturan staf), directing (pengarahan) dan

${ }^{17}$ Sulistyo-Basuki, Pengantar Ilmu Perpustakaan (Jakarta: Gramedia Pustaka Utama, 1993), 9. 
controlling (pengendalian). ${ }^{18}$ Selanjutnya manajemen perpustakaan sekolah/madrasah harus berpedoman kepada lima aspek tersebut, yaitu sebagai berikut:

1. Perencanaan (Planning)

Perencanaan merupakan salah satu aspek yang sangat penting dalam proses pengelolaan perpustakaan sekolah/madrasah. Ada beberapa hal penting yang harus dipikirkan dalam tahap perencanaan. Pertama adalah menentukan tujuan perpustakaan sekolah/madrasah, dalam menentukan tujuan, pustakawan madrasah atau sekolah dapat bekerjasama dengan guru untuk menentukan materi atau bahan-bahan yang sesuai dengan tingkat pendidikan, untuk menentukan keterampilan yang dibutuhkan oleh siswa, untuk membantu dalam penyediaan bahan sesuai dengan mata pelajaran yang diajarkan.

Kedua adalah mengidentifikasi pemakai dan kebutuhannya, mengelola perpustakaan untuk memenuhi kebutuhan para pemakainya. Bahan-bahan atau sumber informasi yang ada di perpustakaan perlu diatur sebaik mungkin sehingga guru maupun siswa yang memerlukannya dapat memperoleh dengan cepat, tepat dan akurat.

2. Pengorganisasian (Organizing)

Pengorganisasian atau pengaturan perpustakaan madrasah atau sekolah merupakan tanggung jawab pustakawan sekolah/madrasah. Organizing merupakan aspek manajemen yang menyangkut penyusunan organisasi manusia dan bahan atau materi. Kegiatan ini meliputi, (a) pengaturan pelayanan peminjaman yang efisien kepada staf pengajar maupun siswa, (b) menyediakan sistem yang efisien mengenai pelayanan pemesanan bahan atau koleksi yang ada di sekolah, (c) memberikan sistem yang fleksibel bagi siswa baik perorangan maupun kelompok serta staf pengajar untuk menggunakan perpustakaan sekolah sebagai tujuan proses belajar mengajar, (d) menjalankan suatu sistem yang memungkinkan sumber-sumber informasi dalam bentuk perangkat keras, (e) mengatur produksi sumber belajar dalam perpustakaan sekolah (jika ada) dan (f) mengawasi dan mengatur pekerjaan bagi pustakawan atau staf perpustakaan yang lain.

3. Pengaturan Staf (Staffing)

Staffing adalah kegiatan pengaturan, pemantauan dan pembinaan staf sesuai tugas dan tanggung jawab yang diberikan berdasarkan kemampuan dan bidang keterampilan yang dimiliki. Dalam kegiatan staffing ini, seorang pustakawan sekolah/madrasah harus mengetahui teknik dan proses yang diperlukan dalam seleksi dan penerimaan staf

18Mohammad Mansyur, Manajemen Perpustakaan Sekolah, 9-14. 
(staff recruitment), training atau pelatihan staf, berkomunikasi dengan staf dan pelayanan kepada staf.

4. Pengarahan (Directing)

Dalam konteks perpustakaan sekolah, pengarahan merupakan tanggung jawab pimpinan perpustakaan. Dengan kata lain peran seorang pimpinan benarbenar diperlukan dalam mendorong staf yang dipimpinnya sehingga mereka dapat bekerja seoptimal mungkin untuk mencapai tujuan yang diinginkan.

5. Pengendalian (Controlling)

Pustakawan sekolah/madrasah harus menyadari pentingnya kontrol

di suatu organisasi, termasuk perpustakaan. Hal-hal yang perlu diperhatikan dalam aspek kontrol di perpustakaan sekolah/madrasah diantaranya adalah (a) selalu menyadari tujuan yang sedang dilaksanakan, (b) menghindari kegiatan yang tidak efisien, (c) evaluasi terhadap pelayanan yang telah dilakukan. ${ }^{19}$

Konsep dasar pengelolaan perpustakaan sekolah/madrasah terkait dengan tujuan, fungsi dan tugas penyelenggaraan lembaga pendidikan itu sendiri. Perpustakaan merupakan komponen instrumental dari sekolah/madrasah sebagai lembaga pendidikan formal. Tugas, fungsi dan tanggung jawab perpustakaan adalah untuk mendukung, memelihara dan memperkaya kualitas proses pembelajaran di sekolah/madrasah untuk mencapai tujuan yang optimal. Perpustakaan sebagai sumber dan tempat belajar perlu diposisikan secara fungsional dalam proses belajar siswa, sehingga mampu memberikan layanan yang lebih bermakna.

Untuk mengelola perpustakaan sekolah/madrasah yang fungsional perlu mengacu kepada kurikulum. Secara teknis dapat disimak dari strategi pembelajaran yang dilakukan oleh guru-guru. Penampilan guru dalam proses pembelajaran menempati posisi kunci bagi keberhasilan pelayanan perpustakaan. Guru sebagai organisator kegiatan belajar siswa, secara fungsional memiliki pengaruh yang cukup besar untuk mendorong peserta didik mendayagunakan perpustakaan. Oleh karenanya dalam mengelola perpustakaan sekolah/madrasah perlu memahami dua hal. Pertama adalah pemahaman kurikulum sekolah/madrasah secara esensial dan elaboratif, sebagaimana yang tercantum dalam rencana pelaksanaan pembelajaran (RPP). Kedua adalah strategi pembelajaran yang dilakukan oleh guru-guru mata pelajaran yang dikaitkan dengan bentuk kegiatan belajar siswa dan pendayagunaan sumber belajar.

Pelayanan perpustakaan dan proses pembelajaran di kelas perlu merupakan kesatuan yang terintegrasi dengan baik. Keduanya harus saling mengisi dan saling mendukung yang berfokus pada pemeliharaan dan

${ }^{19}$ Ibid, 35-39. 
peningkatan kualitas belajar siswa.

Berdasarkan ketentuan yang telah ditetapkan oleh pemerintah, sekolah/madrasah merupakan lembaga pendidikan formal tingkat dasar dan menengah, para peserta didiknya dipersiapkan untuk melanjutkan pendidikan ke jenjang lebih tinggi dan memasuki kehidupan di lingkungan masyarakat yang lebih luas.

Peraturan Pemerintah Nomor 29 Ttahun 1990, Bab II Pasal 2 menyatakan bahwa pendidikan bertujuan untuk (1) meningkatkan pengetahuan siswa untuk melanjutkan pendidikan pada jenjang yang lebih tinggi dan untuk mengembangkan diri sejalan dengan perkembangan ilmu pengetahuan, teknologi dan kesenian, (2) meningkatkan kemampuan siswa sebagai anggota masyarakat dalam mengadakan hubungan timbal balik dengan lingkungan sosial, budaya dan alam sekitar.

Sejalan dengan itu, secara khusus telah ditatapkan tujuan pendidikan pada madrasah yang tercantum dalam Surat Keptusan Menteri Agama RI Nomor 373 Tahun 1993 dalam Bab II sebagai berikut, (1) menyiapkan siswa untuk melanjutkan pendidikan pada jenjang pendidikan lebih tinggi, (2) menyiapkan siswa agar mampu mengembangkan diri sejalan dengan perkembangan ilmu pengetahuan, teknologi dan kesenian yang dijiwai ajaran agama Islam, (3) menyiapkan siswa agar mampu menjadi anggota masyarakat dalam mengadakan hubungan timbal balik dengan lingkungan sosial, budaya dan alam sekitar yang dijiwai suasama keagamaan.

Pemahaman tentang kurikulum madrasah seperti yang telah dikemukakan, perlu dikaitkan dengan pemahaman secara analitik terhadap tujuan pendidikan. Artinya rumusan tujuan pendidikan diterjemahkan kedalam bentuk dan program kurikulum madrasah dan proses pembelajaran. Keberhasilan pengelolaan perpustakaan terletak pada kemampuan pustakawan dalam memfasilitasinya, maksudnya mendukung, melengkapi, memelihara, meningkatkan dan memperkaya proses pembelajaran.

Perpustakaan sekolah/madrasah merupakan instrumen pembelajaran utama yang harus tersedia yang keberadaannya merupakan keharusan demi dapat terselenggarakannya proses pembelajaran yang baik. Perpustakaan sering disebut "jantung pendidikan" oleh karenanya secara operasional, pengelolaan perpustakaan harus benar-benar diposisikan secara tepat.

Peran perpustakaan sekolah/madrasah sangat penting dalam mendukung proses belajar-mengajar, karena perpustakaan mendorong siswa untuk memiliki kebiasaan membaca yang seharusnya terbentuk sejak dini. Setiap guru diharapkan dapat mengembangkan keingin tahuan siswa tentang buku-buku dan dapat mendorong siswa untuk mulai mencintai buku. Selain itu perpustakaan diharapkan memiliki koleksi yang menarik minat siswa untuk membacanya. Perpustakaan madrasah juga harus mempunyai peranan dalam 
mendukung siswa belajar. Diharapkan memiliki koleksi yang mendukung peningkatan pemahaman siswa terhadap mata pelajaran yang mereka pelajari di madrasah, dan dapat meningkatkan pengetahuan mereka tentang dunia. Selain itu perlu adanya koleksi yang memiliki informasi tentang sejarah, komoditi dan budaya daerah. Dengan demikian pemahaman siswa akan semakin meningkat terhadap kebudayaan daerahnya sendiri, yang akhirnya akan timbul rasa banggga terhadap daerahnya.

Berdasarkan uraian di atas, ada beberapa fungsi perpustakaan sekolah/madrasah adalah sebagai berikut, (1) sebagai pusat informasi dan ilmu pengetahuan, (2) sebagai pusat pendidikan, (3) sebagai pusat penelitian literatur, yaitu dengan memberikan bimbigan dan mendorong para siswa agar tumbuh dan berkembang kebiasaan belajar mandiri dan belajar seumur hidup, (4) sebagai tempat rekreasi, yaitu dengan menyediakan sarana hiburan dengan cara menyediakan buku-buku yang sehat dan menyenangkan dalam bentuk karya ilmiah populer dan fiksi, selain itu menyediakan koleksi film, audio dan sebagainya, (5) sebagai sumber inspirasi, yaitu dengan membimbing dan mendorong siswa agar aktif dan kreatif baik dalam mencari informasi dan ilmu pengetahuan, serta menuliskan kembali sebagai suatu karya yang baru, (6) sebagai pusat belajar, baik secara mandiri maupun dengan bimbingan para guru.

Berdasarkan tugas dan fungsi perpustakaan tersebut di atas, kemudian muncul jenis-jenis perpustakaan. Dalam Undang-Undang RI Nomor 43 Tahun 2007 tentang Perpustakaan pada Bab VII Pasal 20 dijelaskan bahwa jenis-jenis perpustakaan ada lima.

Pertama adalah Perpustakaan Nasional. Perpustakaan nasional adalah perpustakaan yang dikelola oleh pemerintah yang berkedudukan di ibukota negara di Jakarta.

Kedua adalah Perpustakaan Umum. Perpustakaan umum adalah perpustakaan yang dikelola oleh pemerintah provinsi, pemerintah kabupaten/kota, kecamatan atau desa, serta dapat diselenggarakan oleh masyarakat. Tujuan dari perpustakaan umum adalah selain mengelola aset daerah di bidang informasi dan ilmu pengetahuan, juga menyediakan kebutuhan masyarakat dan kelompok dalam bidang informasi, pendidikan, peningkatan diri, rekreasi dan kebudayaan.

Ketiga adalah Perpustakaan Sekolah/Madrasah. Perpustakaan jenis ini adalah perpustakaan yang dikelola oleh sekolah/madarasah tingkat dasar, tingkat menengah pertama dan tingkat atas. Pengelola perpustakaan sekolah/madrasah dinamakan guru pustakawan yang memiliki peranan untuk mengembangkan perpustakaan dengan melakukan penyeleksian, pengadaan, pengorganisasian, pensirkulasian koleksi perpustakaan, serta membuat program-program dalam rangka meningkatkan minat baca siswa dan menumbuhkan keinginan para siswa untuk belajar mandiri. 
Keempat adalah Perpustakaan Perguruan Tinggi. Perpustakaan jenis ini adalah perpustakaan yang melayani masyarakat perguruan tinggi, baik mahasiswa, dosen dan karyawan. Kadang-kadang pengguna di luar perguruan tinggi tersebut mendaftar menjadi anggota perpustakaan, tetapi biasanya mereka harus membayar sesuai dengan kebijakan perpustakaan itu sendiri. Tujuan perpustakaan ini adalah mendukung tujuan institusinya dalam proses belajar mengajar, penelitian dan pengabdian pada masyarakat dengan cara menyediakan informasi dan ilmu pengetahuan serta memberikan pelayanan yang sesuai dengan kebutuhan penggunanya.

Kelima adalah Perpustakaan Khusus. Perpustakaan khusus adalah perpustakaan yang mengoleksi subjek tertentu dan melayani pengguna tertentu. Biasanya perpustakaan khusus ini didirikan dan didanai oleh suatu organisasi dimana penggunanya adalah anggota-anggota dari organisasi tersebut. Maksud dari mengoleksi subjek tertentu adalah koleksi yang dikembangkan oleh perpustakaan ini, sesuai dengan bidang dimana organisasi itu bergerak. Misalnya organisasi yang bergerak di bidang pertanian, maka koleksinya yang mereka kumpulkan yang berkenaan dengan masalah pertanian. Begitu pula perpustakaan masjid, akan mengoleksi buku-buku yang berhubungan dengan masalah bidang agama Islam.

Jenis-jenis perpustakaan di atas diharapkan mampu meningkatkan minat baca di kalangan masyarakat umum. Hal ini dikarenakan minat dan kegemaran membaca tidak dengan sendirinya dimiliki oleh seseorang, termasuk anakanak dalam usia sekolah. Minat baca dapat tumbuh dan berkembang dengan cara dibentuk. Dalam kaitan ini dapat disimak teori rangsangan dan dorongan. Dorongan adalah daya motivasional yang mendorong lahirnya perilaku yang mengarah pada pencapaian suatu tujuan. Dorongan yang dimaksud adalah motivasi tidak hanya untuk perilaku tertentu saja, melainkan perilaku apa saja yang berkaitan dengan kebutuhan dasar yang diinginkan seseorang.

Dorongan-dorongan tersebut dapat muncul dari dalam diri orang tersebut atau dapat dirangsang dari luar. Oleh sebab itu, upaya untuk mengangkat program peningkatan minat dan kegemaran membaca perlu melibatkan unsur (a) siswa sekolah/madrsah di semua jenjang, (b) guru sekolah, kepala sekolah, pengawas sekolah, (c) sekolah dengan berbagai program kegiatan yang dapat menunjang pengkondisian tumbuhnya minat dan kegemaran membaca, (d) orang tua di rumah, (e) lingkungan masyarakat di luar sekolah dan rumah, (f) lembaga-lembaga masyarakat yang berminat terhadap pengembangan minat dan kegemaran membaca, misalnya pondok baca, (g) pemerintah melalui berbagai program yang dikembangkan. 
Motivasi yang berasal dari siswa merupakan dorongan yang bersifat internal, sedangkan dorongan dari pihak lainnya bersifat eksternal. Dengan kata lain jika akan merumuskan strategi peningkatan minat dan kegemaran membaca siswa, maka dua model strategi tersebut patut dipertimbangkan, yaitu model strategi yang didasarkan pada motivasi internal dan model yang digerakkan oleh motivasi eksternal.

Setidaknya terdapat tiga dimensi pengembangan minat dan kegemaran membaca yang perlu dipertimbangkan. Pertama adalah dimensi edukatif pedagogik. Dimensi ini menekankan tindak-tindak motivasional apa yang dilakukan para guru di kelas, untuk semua mata pelajaran yang akhirnya para siswa tertarik dan memiliki minat terhadap kegiatan membaca untuk tujuan apa saja. Paradigma pengajaran saat ini adalah berpusat pada siswa, maka pengembangan minat baca hendaknya dimulai dari aktivitas belajar sehari-hari di kelas.

Kedua adalah dimensi sosio kultural. Dimensi ini mengandung makna bahwa minat baca siswa dapat digalakkan berdasarkan hubunganhubungan sosial dan kebiasaan siswa sebagai anggota masyarakat. Misalnya dalam masyarakat paternalistik, orang tua atau pemimpin selalu menjadi panutan. Dalam hal ini jika yang dijadikan panutan memiliki minat baca, maka dapat diprediksi bahwa siswa juga dengan sendirinya terbawa situasi tersebut, artinya siswa akan memiliki sikap dan kegemaran membaca.

Ketiga adalah dimensi perkembangan psikologis. Siswa usia sekolah pada jenjang SD/SMP/SMA merupakan usia anak pra-remaja. Tahap pertengahan masa anak-anak didominasi dengan fungsi pengamatan, fungsi rasa ingin tahu yang cukup kuat. Pada masa ini perlu dipertimbangkan secara sungguh-sungguh dalam upaya memotivasi kegemaran membaca siswa. Pengamatan membaca yang jitu biasanya melalui ilustrasi gambar. Penalaran intelektual mudah dirangsang melalui diskripsi yang dikotomis, argumentasi yang menggugah.

Peran perpustakaan sangat sentral dalam membina dan menumbuhkan kesadaran membaca. Kegiatan membaca tidak bisa dilepaskan dari keberadaan dan tersedianya bahan bacaan yang memadai baik dalam segi jumlah maupun dalam kualitas bacaan.

Pada aspek lain minat baca senantiasa perlu dikembangkan. Di lingkungan siswa usia sekolah usaha pengembangan minat baca dapat dilakukan dengan prinsip jenjang dan pikat. Prinsip pertama perlu adanya usaha untuk memikat pengguna untuk mulai menyenangi kegiatan membaca. Prinsip kedua perlu ada upaya untuk mengkondisikan perlunya penyediaan meteri bacaan yang sesuai dengan perkembangan anak yang dapat memperkuat minat baca anak, yang senantiasa terus mendorong anak untuk maju menuju pada kegiatan membaca yang berkualitas. 
Beberapa usaha yang dapat dilakukan untuk meningkatkan kegemaran membaca siswa melalui perpustakaan meliputi enam hal. Pertama adalah menyediakan bahan bacaan yang diminati siswa, yang sesuai dengan keragaman tingkat perkembangan siswa. Kedua adalah menjadikan perpustakaan sekolah sebagai tempat yang menyenangkan bagi siswa melalui penataan yang bagus, dengan pelayanan yang ramah. Ketiga adalah membuat promosi dan kegiatan pengembangan minat dan kegemaran membaca dengan memanfaatkan perpustakaan sekolah.

Keempat adalah memberikan tugas tambahan kepada siswa di luar kelas. Pemberian tugas tambahan ini tentunya berkaitan dengan terbatasnya jam pelajaran di dalam kelas. Oleh sebab itu guru sebaiknya senantiasa mendorong siswa untuk lebih banyak membaca di luar jamjam sekolah (di rumah). Tugas membaca dapat dipantau dengan membuat laporan, resensi buku, atau membuat laporan garis besar isi buku yang telah dibacanya (sinopsis) dengan memanfaatkan bacaan yang tersedia di perpustakaan.

Kelima adalah tersedianya waktu bagi siswa untuk berkunjung ke perpustakaan baik secara perseorangan maupun klasikal yang sekaligus merupakan jam belajar di perpustakaan. Keenam adalah mengintegrasikan perpustakaan dalam kegiatan belajar mengajar. ${ }^{20}$

\section{Peran Pustakawan}

Pustakawan adalah orang yang ahli membantu memudahkan akses ke informasi dan ilmu pengetahuan yang dibutuhkan oleh para masyarakat dan pengguna lain. Sedangkan menurut Surat Keputusan Menteri Negara Pendayaan Aparatur Negara Nomor 33 Tahun 1998, kepustakawanan adalah ilmu dan profesi di bidang pembinaan dan pengembangan serta penyelenggaraan perpustakaan, dokumentasi dan informasi. ${ }^{21}$ Berdasarkan definisi ini, maka seorang yang bergerak dalam bidang informasi dan ilmu pengetahuan dituntut untuk memiliki keahlian dan ketrampilan dalam mengelola informasi dan ilmu pengetahuan serta memahami kebutuhan para penggunanya.

Maksud dari memiliki keterampilan dan keahlian dalam mengelola informasi dan ilmu pengetahuan adalah bahwa sebagai pustakawan, harus memiliki keterampilan dan keahlian dalam, (1) memahami cara mencari informasi dan ilmu pengetahuan, baik yang berbentuk cetak maupun non cetak, yang selanjutnya memahami cara pengadaannya, (2) memahami cara menggunakan informasi dan ilmu pengetahuan, terutama pada bahan-bahan yang berupa non-cetak: CD room, video, kaset, microfilm dan sebagainya, (3) memahami cara mengorganisasi informasi dan ilmu pengetahuan yang

20Darmono, “Pengembangan Perpustakaan Sekolah," 10.

${ }^{21}$ Mohammad Mansyur, Manajemen Perpustakaan Sekolah, 35-39. 
berdasarkan pada kemudahan, kecepatan dan ketepatan bagi pengguna dalam menemukan kembali informasi dan ilmu pengetahuan yang pengguna butuhkan, (4) memahami cara memberikan pendidikan penelusuran informasi dan ilmu pengetahuan pada pengguna, bahwa salah satu tugas pustakawan adalah memberikan pendidikan kepada penggunanya dalam mencari informasi yang baik dan benar secara mandiri tanpa bantuan pustakawan, (5) memahami bentuk-bentuk layanan referensi, dari menjawab pertanyaan yang paling sederhana sampai kepada membantu pengguna dalam mencari sumber informasi untuk penelitian, (6) memahami cara mengatur tata ruang perpustakaan yang berdasarkan kepada kenyamanan dan keefektifan ruang perpustakaan, (7) memahami cara melakukan tindakan pencegahan dari sumber-sumber kerusakan pada koleksi dan memahami tindakan penyelamatan terhadap koleksi, jika ada musibah, (8) memahami manajemen perpustakaan yang baik dan benar, sehingga tujuan perpustakaan akan tercapai.

Kegiatan-kegiatan pengelolaan perpustakaan di atas harus berorientasi kepada pengguna/pemustaka, di mana pustakawan harus memahami penggunanya, misalnya latar belakang, pendidikan, agama, sosial, budaya, umur, ekonomi, pekerjaan dan lain sebagainya. Dengan hal-hal tersebut, pustakawan akan mudah untuk mengetahui keinginan informasi dan ilmu pengetahuan yang dibutuhkan oleh penggunanya. Untuk meningkatkan keterampilan dan keahlian dalam bidang pengelolaan informasi dan ilmu pengetahuan, pustakawan dapat mengikuti berbagai pendidikan dan pelatihan. Pelatihan perpustakaan seringkali diadakan oleh Kementerian Agama ataupun Perpustakaan Provinsi.

Dalam melakukan pengembangan karir, seorang pegawai negeri sipil yang bekerja di perpustakaan di instansi pemerintah dapat mengajukan diri untuk menjadi tenaga fungsional pustakawan. Di mana untuk menjadi tenaga fungsional pustakawan telah diatur dalam Peraturan Menteri Pendayagunaan Aparatur Negara dan Reformasi Birokrasi Republik Indonesia Nomor 9 Tahun 2014 Tentang Jabatan Fungsional Pustakawan dan Angka Kreditnya, dan Peraturan Bersama Kepala Perpustakaan Nasional Republik Indonesia dan Kepala Badan Kepegawaian Negara Republik Indonesia Nomor 8 Tahun 2014 dan Nomor 32 Tahun 2014.

Pemahaman masyarakat umum yang menganggap bahwa perpustakaan "hanya" tempat menyimpan buku, menyebabkan masih dijumpainya masyarakat yang merendahkan profesi pustakawan dan staf yang bekerja di perpuskaan. Karena adanya kesan bahwa pustakawan dan staf yang bekerja di perpustakaan adalah orang-orang buangan, yaitu orang yang bekerja di perpustakaan hanyalah orang-orang yang menata buku saja tanpa didasari oleh keahlian dan kemampuan keilmuan. Kesan ini karena pemahaman masyarakat terhadap profesi pustakawan sangat kurang, sehingga masih sering dijumpai masyarakat enggan bertanya kepada pustakawan, apabila mereka mengalami 
kesulitan dalam menemukan informasi atau informasi yang dibutuhkan.

Pertanyaan mereka hanya sebatas lokasi buku dan tidak sampai pada isi informasi yang ada di buku. Kesan ini, sangat mempengaruhi perkembangan perpustakaan dan minat baca pada masyarakat. Kesan ini semestinya tidak perlu terjadi, jika masyarakat telah memahami fungsi dan peranan perpustakaan dan pustakawan.

Hal ini dikarenakan perpustakaan sebagai salah satu sumber ilmu pengetahuan sangat penting keberadaannya bagi masyarakat, terutama perpustakaan sekolah yang menjadi wadah tempat disimpannya alat-alat bantu anak-anak untuk belajar, yaitu literatur. Optimalisasi fungsi perpustakaan sekolah/madrasah tidak terbatas pada pembenahan dan peningkatan manajemen perpustakaan sekolah, melainkan juga harus disertai kesadaran dari seluruh sumber daya manusia (SDM) yang berada di lingkungan sekolah, khususnya guru dan kepala sekolah, untuk memberikan teladan yang baik terkait kegiatan membaca. Tanpa adanya dorongan dan model panutan dari para guru dan seluruh SDM yang ada, perpustakaan tidak akan berfungsi secara optimal meskipun memiliki manajemen yang baik. Eksistensi perpustakaan hanya berguna bagi para siswa yang memiliki minat baca yang tinggi. ${ }^{22}$

Untuk mewujudkan manajemen perpustakaan yang baik, maka pengelola perpustakaan disyaratkan harus (1) mengembangkan kemampuan profesional sebagai guru-pustakawan, (2) memperhatikan kemampuan yang diperlukan dan prosedur yang dibutuhkan untuk dapat mengelola perpustakaan secara efektif, (3) mengembangkan kebijakan dan prosedur dengan prinsip-prinsip yang mengaktualisasikan visi dari perpustakaan sekolah, (4) memperlihatkan keterkaitan antara sumbersumber informasi, tujuan dan prioritas sekolah, serta program perpustakaan, (5) menunjukkan peran guru-pustakawan melalui rencana manajemen.

Pengelola perpustakaan harus dapat mengelola perpustakaan secara efektif, sehingga kebijakan sekolah, yayasan, pemerintah dan kebijakan lainnya dapat dijalankan, dan prosedur yang dijalankan sesuai dengan kebutuhan-kebutuhan sekolah. Kebijakan antara lain berkaitan dengan sumber pendanaan, tenaga pengelola, dukungan terhadap pengelola perpustakaan dan faktor-faktor lain yang berhubungan. Hal-hal yang perlu dilakukan pengelola perpustakaan berkaitan dengan prosedur dan kebijakan adalah (1) melihat kembali sumber-sumber yang dimiliki dan mendefinisikannya sesuai kebutuhan dan perkembangan kebijakan sekolah, (2) melihat, memperhatikan dan memperbaharui prosedur-prosedur,

${ }^{22}$ Muzdalifah M. Rahman, “Mengaktifkan Perpustakaan Sekolah,” Jurnal STAIN Kudus (2016), 181-190. 
antara lain sirkulasi, pemesanan bahan pustaka, (3) membuat sebuah pernyataan visi perpustakaan sekolah yang sesuai dengan kebijakan yang ada, (4) memperhatikan kebijakan-kebijakan baru dari sekolah mengenai perpustakaan sekolah.

Proses yang berkaitan dengan kebijakan dan prosedur ini harus memperhatikan prinsip-prinsip dalam kelompok yang mempunyai minat berbeda di sekolah. Oleh karena itu, perlu dilakukan peninjauan kembali pada kebijakan yang telah dibuat, agar tidak menimbulkan permasalahan atau keluhan dari pihak yang terkait. Selain itu yang terpenting adalah dalam setiap membuat suatu kebijakan atau prosedur harus selalu mempertimbangkan visi, kebutuhan, dan keadaan dari sekolah atau lembaga induknya. Hal tersebut patut diperhitungkan karena pada prinsipnya perpustakaan sekolah sebagai cermin visi dan misi sebuah lembaga pendidikan sekolah. ${ }^{23}$

\section{KESIMPULAN}

Perpustakaan yang diselenggarakan di tingkat sekolah/madrasah berfungsi untuk mendukung tercapainya tujuan dari proses pembelajaran dan menumbuhkan minat baca siswa sehingga tumbuh kesadaran untuk dapat belajar mandiri, sehingga kualitas sumber daya manusia mampu terwujud. Perpustakaan memberikan kepuasan tentang pengetahuan di luar kelas. Perpustakaan sekolah/madrasah berperan dalam proses pendidikan sepanjang hayat.

Manajemen perpustakaan merupakan salah satu kajian tentang apa dan baigaimana cara yang dapat dilakukan, baik melalui teori maupun praktek agar perpustakaan dapat dikelola dengan berdaya guna. Manajemen perpustakaan sekolah meliputi perencanaan, pengorganisasian, pengaturan staf, pengarahan dan pengendalian. Jenis-jenis perpustakaan meliputi Perpustakaan Nasional (Perpusnas), perpustakaan umum, perpustakaan sekolah, perpustakaan perguruan tinggi dan perpustakaan khusus.

Setidaknya terdapat tiga dimensi pengembangan minat dan kegemaran membaca siswa yang perlu dipertimbangkan, yaitu dimensi edukatif-pedagogik, dimensi sosio-kultural dan dimensi psikologis. Beberapa usaha yang dapat dilakukan untuk meningkatkan kegemaran membaca siswa adalah, (1) menyediakan bahan bacaan yang diminati siswa dan sesuai dengan keragaman tingkat perkembangan siswa, (2) menjadikan perpustakaan sekolah sebagai tempat yang menyenangkan bagi siswa melalui penataan yang bagus dan pelayanan yang ramah, (3) membuat promosi dan kegiatan pengembangan minat dan kegemaran membaca, (4) memberikan tugas tambahan kepada siswa di luar kelas, (5) tersedianya waktu bagi siswa untuk berkunjung ke perpustakaan baik secara perseorangan maupun klasikal.

23Ibid, 190-199. 
Pustakawan adalah orang yang ahli membantu memudahkan akses ke informasi dan ilmu pengetahuan yang dibutuhkan oleh para masyarakat dan pengguna lain. Seseorang yang bergerak dalam bidang informasi dan ilmu pengetahuan dituntut untuk memiliki keahlian dan ketrampilan dalam mengelola informasi dan ilmu pengetahuan serta memahami kebutuhan para penggunanya. Maksud dari memiliki keterampilan dan keahlian dalam mengelola informasi dan ilmu pengetahuan adalah bahwa sebagai pustakawan harus memiliki delapan kompetensi. Pengelola perpustakaan juga harus dapat mengelola perpustakaan secara efektif, sehingga kebijakan sekolah, yayasan, pemerintah dan kebijakan lainnya dapat dijalankan dan prosedur yang dijalankan sesuai dengan kebutuhan-kebutuhan sekolah.

\section{DAFTAR PUSTAKA}

Badrudin, Arief Rachman. "Manajemen Perpustakaan Sekolah dalam Merealisasikan Pengembangan Kurikulum 2013," Jurnal Islamic Management, Vol. 2 No. 1 (2019).

Darmono. Manajemen dan Tata Kerja Perpustakaan Sekolah. Jakarta: Gramedia Widiasarana Indonesia, 2001.

Hadi, Sutrisno. Metodologi Research. Yogyakarta: Andi Offset, 1987.

https://perpusda.bengkuluprov.go.id/2018/02/12/peranan-perpustakaansekolah-dalam-proses-belajar-mengajar/, diunduh 12 Agustus 2021, pukul 20.07 WIB.

Kartika, Ika. "Upaya Pemanfaatan Perpustakaan Sekolah Dalam Meningkatkan Minat Baca Siswa Di Sekolah Dasar Negeri 1 Pamengkang Kecamatan Mundu Kabupaten Cirebon," Jurnal EduBase, Vol. 1 No. 1 (2020).

Kusuma, Arja. "Dukungan Perpustakaan dalam Proses Pembelajaran Online di Universitas Islam Negeri Sunan Kalijaga pada Masa Pandemic Covid-19," Jurnal Libria, Vol. 12 No. 1 (Juni 2020).

Mangnga, Alias. "Peran Perpustakaan Sekolah Terhadap Proses Belajar Mengajar di Sekolah," Jurnal Jupiter, Vol. XIV No. 1 (2015).

Mansyur, Mohammad. Manajemen Perpustakaan Sekolah/Madrasah. Jombang: Ainun Media, 2021.

Muhajir, Noeng. Metodologi Penelitian Kualitatif. Yogyakarta: Reke Sarasen, 1994.

Niles, Mathew B. dan A. Michael Haberman. Qualitatif Data Analisis. London: tp, 1986.

Novriliam, Rio. "Pemanfaatan Perpustakaan Sekolah Sebagai Pusat Sumber Belajar di SDN 23 Painan Utara," Jurnal Ilmu Informasi Perpustakaan dan Kearsipan, Vol. 1 No. 1 (September 2012).

Rahadian, Gallint. "Peran Perpustakaan dalam Meningkatkan Budaya Gemar Membaca," Jurnal Kajian Informasi dan Perpustakaan, Vol. 2 No. 1 (2014).

Rahman, Muzdalifah M. "Mengaktifkan Perpustakaan Sekolah," Jurnal STAIN Kudus (2016). 
Sudarsono, Blasius. "Perpustakaan Sekolah Suatu Keniscayaan dalam Penyelenggaraan Pendidikan Formal," Jurnal Acarya Pustaka, Vol. 1 No. 2 (2015).

Sulistyo-Basuki. Pengantar Ilmu Perpustakaan. Jakarta: Gramedia Pustaka Utama, 1993.

Sutarno NS. Membina Perpustakaan Desa. Jakarta: CV. Sagung Seto, 2008. 